\title{
$\begin{array}{ll}\text { Research Square } & \begin{array}{l}\text { Preprints are preliminary reports that have not undergone peer review. } \\ \text { They should not be considered conclusive, used to inform clinical practice, } \\ \text { or referenced by the media as validated information. }\end{array}\end{array}$
}

\section{Genome-wide SNPs Detect Fine-scale Genetic Structure in Threatened Populations of Squirrel Glider Petaurus Norfolcensis}

\author{
Monica Knipler ( mk972@uowmail.edu.au ) \\ University of Wollongong Faculty of Science Medicine and Health https://orcid.org/0000-0002-7489-9552 \\ Mark Dowton \\ University of Wollongong Faculty of Science Medicine and Health \\ John Clulow \\ The University of Newcastle Faculty of Science \\ Ninon Meyer \\ University of Göttingen: Georg-August-Universitat Gottingen \\ Katarina M. Mikac \\ University of Wollongong Faculty of Science Medicine and Health
}

\section{Research Article}

Keywords: Petaurus norfolcensis, glider, Petauridae, fragmentation, genetic differentiation, urbanisation

Posted Date: August 4th, 2021

DOI: https://doi.org/10.21203/rs.3.rs-717093/v1

License: (c) (i) This work is licensed under a Creative Commons Attribution 4.0 International License. Read Full License

Version of Record: A version of this preprint was published at Conservation Genetics on March 26th, 2022. See the published version at https://doi.org/10.1007/s10592-022-01435-9. 


\section{Abstract}

Australian arboreal mammals are experiencing significant population declines, particularly due to land clearing and resulting habitat fragmentation. The squirrel glider, Petaurus norfolcensis, is a threatened species in New South Wales, with a stronghold population in the Lake Macquarie Local Government Area (LGA) where fragmentation due to urbanization is an ongoing problem for the species conservation. Here we report on the use of squirrel glider mitochondrial (385 bp cytochrome b gene, 70 individuals) and nuclear DNA (6,812 SNPs, 87 individuals) markers to assess their population genetic structure and connectivity across 14 locations sampled in the Lake Macquarie LGA. The mitochondrial DNA sequences detected evidence of a historical genetic bottleneck, while the genome-wide SNPs detected significant population structure in the Lake Macquarie squirrel glider populations at scales as fine as one kilometer. There was no evidence of inbreeding within patches, however there were clear effects of habitat fragmentation and biogeographical barriers on gene flow. A least cost path analysis identified thin linear corridors that have high priority for conservation. These areas should be protected to avoid further isolation of squirrel glider populations and the loss of genetic diversity through genetic drift.

\section{Introduction}

The hollow-dependent, arboreal squirrel glider (Petaurus norfolcensis, Kerr) is an Australian marsupial that forms monogamous social groups (Sharpe and Goldingay 2007), and is listed as a threatened species in New South Wales (Vulnerable: Threatened Species Conservation Act 1995). Dry sclerophyll forest is the preferred habitat for squirrel gliders, with populations found in remnant bushland along the highly urbanised east coast of Australia and the Great Dividing Range (Pavlova et al. 2010). In addition to their reliance on tree hollows, more than $50 \%$ of their diet depends on the nectar, pollen and sap of five plant species (belonging to the Eucalyptus, Corymbia, Melaleuca, Banksia genera) (Ball et al., 2009). Eucalyptus forests have experienced the greatest deforestation of Australian vegetation and $80 \%$ of remnants have been modified by human activity (Bradshaw 2012). Habitat loss and fragmentation are the main threats to squirrel gliders as described in the Action Plan for Australian Mammals (Goldingay and Sharpe 2004; Woinarski et al. 2014). The fragmentation of forests can lead to a loss of squirrel glider genetic diversity through genetic drift (Frankham et al. 2002) while also increasing intraspecific competition for tree hollows and other habitat resources.

Squirrel gliders rely on trees for dispersal, and as such gene flow between populations can be obstructed by gaps in canopy that exceed their maximum glide distance of 70 meters or by short trees that do not support a glide angle of 28.5 degrees (Van der Ree, 2002; Van Der Ree et al., 2004; Goldingay and Taylor, 2009). Additionally, squirrel gliders generally avoid remnant trees in the urban matrix as they are sensitive to light pollution, road density and associated noise (Francis et al., 2015). Limited access to food, as a result of land clearing and fragmentation, reduces the effective population size of squirrel gliders (Sharpe 2004). Evidence suggests that small isolated patches must be linked to a larger metapopulation to prevent inbreeding depression and localised extinction (Goldingay and Sharpe, 2004; Van Der Ree et al., 2004). Many studies have relied on radio-tracking to infer connectivity of patches and dispersal of squirrel gliders (van der Ree and Bennett, 2003; Sharpe and Goldingay, 2007; Goldingay et al., 2010; Brearley et al., 2011; Soanes et al., 2015), however few have examined genetic structure and gene flow to make this inference.

Large-scale studies have compared the genetic diversity of squirrel gliders across the entire east coast of Australia (Pavlova et al. 2010; Taylor et al. 2011), but only one has examined the effect of fragmentation on a fine-scale (e.g. Goldingay et al. 2013). Assessing the localised, fine-scale genetic structure of squirrel glider populations would assist with the development and utilisation of local conservation management strategies in areas where they are already listed as a threatened species. Currently squirrel glider research has only used mitochondrial (cytochrome b) and microsatellite DNA markers to examine genetic structure (Pavlova et al. 2010; Taylor et al. 2011; Goldingay et al. 2013; Dudaniec et al. 2016), and researchers are yet to take advantage of the power of next-generation sequencing technology and single nucleotide polymorphisms (SNPs).

SNPs are the most common form of sequence variation, characterised by single base nucleotide changes in the genome that differ among individuals (Brumfield et al. 2003). Advances in next-generation sequencing means that tens of thousands of bi-allelic, co-dominant SNP markers can be detected in the genome (Kumar et al. 2012). SNPs have wider genome coverage than microsatellites and population samples of four individuals are enough to identify population structure (Liu et al. 2005; Shi et al. 2010; Lah et al. 2016; Dussex et al. 2018). Genomewide SNP discovery with next-generation sequencing is gaining importance in conservation genetic research on threatened species given that small sample sizes are common. SNPs have effectively informed conservation management of threatened Australian marsupials in recent years including the greater bilby, Macrotis lagotis and western barred bandicoot, Perameles bougainville (White et al. 2018), koala, Phascolarctos cinereus (Kjeldsen et al. 2016) and the Tasmanian devil, Sarcophilus harrisii (Wright et al. 2019). SNPs would therefore be extremely valuable in assessing the effects of habitat fragmentation on squirrel glider populations at a fine-scale.

The emergence of landscape genetics (Manel et al. 2003) contributed substantially to the field of ecology, evolution, and species conservation in recent decades. Among others, landscape genetics combines population genetics, landscape ecology and spatial analytical

Page 2/21 
techniques to quantify the effects of landscape composition, configuration, and matrix quality on gene flow using neutral genetic data (Balkenhol et al. 2015). It has allowed the field to move from the more traditional isolation-by-distance analyses to explain differences in the genetic structure of populations that drill down further into movement and dispersion dynamics. Estimates of gene flow can be tested against measures of effective geographic distance to find estimates of landscape resistance that best fit with the genetic data. Landscape genetics has proven useful to quantify the effects of habitat fragmentation on genetic structure, and identify landscape features that are important for maintaining genetic connectivity between populations within heterogeneous landscapes (e.g. Sharma et al. 2013), as well as pinpoint barriers to gene flow (Cushman and Lewis 2010).

Here we use mitochondrial DNA and genome-wide SNP markers to examine the effect of fragmentation on population structure of threatened squirrel gliders in the Lake Macquarie Local Government Area (LGA). We hypothesised that: (1) squirrel gliders in isolated patches would have low levels of genetic diversity and limited gene flow; (2) squirrel glider populations isolated by biogeographical barriers (Lake Macquarie and the Pacific Ocean) would be highly differentiated from other populations; and (3) landscape heterogeneity (vegetation and land use) would impact the genetic structure and differentiation of squirrel glider populations. This is the first study to report on the genetic structure of the Lake Macquarie LGA squirrel glider metapopulation, despite the LGA being a stronghold population for the species (Smith 2002; Fallding 2015).

\section{Methods}

\section{Study area}

The study was undertaken in the Lake Macquarie LGA, $130 \mathrm{~km}$ north of Sydney, Australia (Fig. 1). Lake Macquarie LGA has experienced a high level of land clearing resulting in fragmentation of forests recognised as critical squirrel glider habitat (Smith 2002; Fallding 2015).In addition to habitat fragmentation, squirrel gliders also face added pressure from biogeographical barriers in the landscape. In this case, there is a large natural saltwater lake that presents a barrier to gene flow in the LGA (Lake Macquarie, $120 \mathrm{~km}^{2}$ ) as well as the Pacific Ocean on the east coast (Fig. 1). Lake Macquarie LGA is a nationally significant area within the distribution of squirrel gliders since it is believed to contain the highest density across their range in the eastern seaboard of Australia (estimated 5000 individuals in the Lake Macquarie - Wyong area, concluded from the Wildlife Atlas records in New South Wales) (Smith 2002; Fallding 2015). Because of this, it is essential to monitor squirrel gliders in the area to ensure habitat fragmentation and biogeographical barriers do not negatively impact upon the conservation status further. 
Table 1

Location information and number of genotyped squirrel gliders $(N)$ that were sampled in the Lake Macquarie area. Mean observed

heterozygosity $\mathrm{H}_{\mathrm{obs}}$ and mean expected heterozygosity $\mathrm{H}_{\mathrm{ex}}$ are reported, as well as the inbreeding coefficient $F_{I S}$. Results are generated from the

filtered SNP dataset (6,812 loci) of 87 individuals. Refer to Fig. 1 for spatial locations.

\begin{tabular}{|llllll|}
\hline Location & Acronym & $\mathbf{N}$ & $\mathrm{H}_{\text {Obs }}$ & $\mathrm{H}_{\text {ex }}$ & $\mathrm{F}_{\text {IS }}$ \\
\hline Croudace Bay & CROB & 2 & 0.190 & 0.123 & -0.545 \\
\hline Dudley Beach Road & DUD & 2 & 0.188 & 0.148 & -0.270 \\
\hline Fernleigh Track (Nth) & FERNN & 10 & 0.175 & 0.152 & -0.151 \\
\hline Fernleigh Track (Sth) & FERNS & 1 & 0.184 & 0.098 & -0.878 \\
\hline George McGregor Park & GMP & 3 & 0.161 & 0.140 & -0.150 \\
\hline Glenrock SCA & GSCA & 12 & 0.181 & 0.168 & -0.077 \\
\hline Ocean Street & OCN & 16 & 0.188 & 0.163 & -0.153 \\
\hline Overhill Road & OR & 7 & 0.172 & 0.148 & -0.162 \\
\hline Ruston Avenue & RA & 2 & 0.168 & 0.136 & -0.235 \\
\hline Red Head Lagoon & RHL & 8 & 0.183 & 0.174 & -0.052 \\
\hline Sunshine Park & SP & 1 & 0.147 & 0.080 & -0.838 \\
\hline Wilton Road (Est) & WR & 15 & 0.192 & 0.189 & -0.016 \\
\hline Wyee Road (Nth) & WYB & 4 & 0.181 & 0.164 & -0.104 \\
\hline Wyee Road (Sth) & WYC & 4 & 0.166 & 0.163 & -0.018 \\
\hline TOTAL & 14 & 87 & & & \\
\hline
\end{tabular}

Squirrel glider trapping locations in the Lake Macquarie LGA were selected through a combination of spatial modelling and visual identification of suitable vegetation. Sites required dens (large hollow bearing trees) and eucalypts (Corymbia maculata, Eucalyptus robusta, E. tereticornis), acacias (Acacia irrorata) and banksias (Banksia spinulosa; Banksia integrifolia) since squirrel gliders are known to feed on their sap, gum and nectar (Ball et al. 2009). Additionally, Smith and Murray (2003) found higher densities of squirrel gliders in the Lake Macquarie area associated with an understory of Xanthorrhoea and Banksia species, and scribbly gum (E. haemastoma or racemosa), smooth-barked apple (Angophora costata) and red bloodwood trees (Corymbia gummifera). Once potential sites were located, BioNet records (NSW Office of Environment and Heritage 2021), spotlighting surveys and/or infrared cameras (Gracanin et al. 2019) were further used to confirm glider presence at a site prior to live trapping.

\section{Sampling of squirrel gliders}

Live trapping was undertaken at 32 locations over a four-year period (Fig. 1) (Table 1). Each site was subject to at least one week of live trapping using 12 traps per site (two rows of six with each trap spaced 50 meters apart), and further focus was given to sites that captured squirrel gliders during this period to increase sample size. Once squirrel gliders were detected at a site, the area was re-trapped every six months to a year across the survey period. A combination of Mawbey traps, Elliot B traps, cage traps and Winning and King pipe traps were used to live trap gliders (Mawbey 1989; Quin 1995; Winning and King 2008). All traps were secured to trees so that the trap entrance was at least two meters from ground height. Each trap contained a bait ball made from a mixture of peanut butter, honey, and oats (Winning and King 2008), leaves for insulation, and a 1:4 ratio of honey:water was sprayed around each trap entrance and up the tree to a height of 6 meters as a further attractant (Sharpe and Goldingay 2007).

Traps were checked each morning at sunrise. Trapped gliders were weighed, sexed, measured (tail length, right hind foot length, head width and head length) and individuals were marked with a metal ear tag or an ear punch combination. Before being released, a DNA sample was collected in the form of ear tissue (or in the early stages of the project, a buccal swab), using a 2 mm metal ear punch (Able Scientific, Australia) that was previously sprayed with $70 \%$ ethanol and flamed for sterilization. Once cooled, a $2 \mathrm{~mm}$ punch was taken from the outside edge of the ear and stored in sterilized vials containing $80-95 \%$ ethanol. DNA was kept at $-20^{\circ} \mathrm{C}$ prior to DNA extraction. The processing of each squirrel glider was limited to a maximum time of five-minutes, and individuals were released on the same tree that they were caught. 


\section{Laboratory procedures}

Genomic DNA was extracted from the buccal swab and ear tissue samples using the One-4-ALL Genomic Miniprep Kit (BioBasic Inc. Ontario, Canada) and DNeasy Blood and Tissue Kit (Qiagen, Hilden, Germany) as per the manufacturer's instructions.

\section{Mitochondrial DNA: cytochrome b gene}

Genomic DNA samples that were extracted from buccal swabs and ear tissue were used for mitochondrial DNA analysis. A 385 base pair fragment of the mtDNA cytochrome b gene was amplified using primer pair L14724 (5'-CGA AGC TTG ATA TGA AAA ACC ATC GTT G-3') and H15149 (5'-AAA CTG CAG CCC CTC AGA ATG ATA TTT GTC CTC A-3') as described by Kocher et al. (1989) and Irwin et al. (1991). PCR products were treated in the post-PCR lab via the ExoSAP-IT ${ }^{\mathrm{TM}}$ enzymatic method (Affymetrix Inc. USB Corp., Cleveland, Ohio) prior to sequencing with an ABI PRISM BigDyeTM Terminator Cycle Sequencing Kit (Applied Biosystems, USA). Sequencing products were cleaned with a precipitation cleanup method and sequences were generated with a 3130xl Genetic Analyzer (Applied Biosystems, Australia), at the University of Wollongong, School of Biological Sciences. Sequences were visually inspected and manually edited using the program ChromasPro v 1.33 (Technelysium Pty Ltd, Brisbane) and aligned using BioEdit v 7.2.6.1 (Hall 1999). Cytochrome b sequences were obtained from 55 squirrel glider samples in the Lake Macquarie LGA, and 15 buccal swab samples that were donated to the project from the Forster region, approximately $130 \mathrm{~km}$ northeast of Lake Macquarie. Therefore, cytochrome b sequences were generated for a total of 70 individual squirrel gliders (Table 2).

Table 2

Cytochrome b data from DNA extracted from buccal swabs and ear tissue: squirrel glider sample size (n), haplotypes, haplotype diversity (h) and nucleotide diversity ( $\pi$ ) for locations in Lake Macquarie and Forster. Refer to Table 1 for further information about habitat fragment acronyms.

\begin{tabular}{|c|c|c|c|c|}
\hline Region & $\mathbf{n}$ & Haplotypes & $\begin{array}{l}\text { h } \\
( \pm S D)\end{array}$ & $\begin{array}{l}\pi \\
( \pm S D)\end{array}$ \\
\hline \multicolumn{5}{|c|}{ Lake Macquarie } \\
\hline GMP & 6 & $\mathrm{H} 01, \mathrm{H} 03$ & $0.600(0.129)$ & $0.00156(0.00034)$ \\
\hline GSCA & 9 & $\mathrm{H03}, \mathrm{HO} 4$ & $0.556(0.090)$ & $0.00144(0.00023)$ \\
\hline$M P^{*}$ & 3 & $\mathrm{H} 02, \mathrm{H} 07$ & $0.667(0.314)$ & $0.00519(0.00245)$ \\
\hline $\mathrm{OCN}$ & 7 & $\mathrm{HO3,} \mathrm{H04}$ & $0.571(0.119)$ & $0.00148(0.00031)$ \\
\hline OR & 4 & $\mathrm{H03}$ & 0 & 0 \\
\hline RA & 6 & $\mathrm{H03,} \mathrm{H06}$ & $0.333(0.215)$ & $0.00087(0.00056)$ \\
\hline $\mathrm{RHL}$ & 5 & $\mathrm{H} 01, \mathrm{H} 03, \mathrm{H} 04$ & $0.800(0.164)$ & $0.00260(0.00072)$ \\
\hline SP & 6 & $\mathrm{H} 04$ & 0 & 0 \\
\hline WR & 5 & $\mathrm{H} 03, \mathrm{H} 05$ & $0.400(0.237)$ & $0.00208(0.00123)$ \\
\hline WYB & 4 & $\mathrm{H03}, \mathrm{H04}, \mathrm{H} 06$ & $0.833(0.222)$ & $0.00260(0.00088)$ \\
\hline Total & 55 & 7 & $0.648(0.052)$ & $0.00232(0.00034)$ \\
\hline \multicolumn{5}{|l|}{ Forster } \\
\hline$G P^{*}$ & 9 & $\mathrm{H03,} \mathrm{H08}$ & $0.389(0.164)$ & $0.00202(0.00085)$ \\
\hline$S W E^{*}$ & 3 & $\mathrm{H03}$ & 0 & 0 \\
\hline$T U N^{*}$ & 3 & $\mathrm{H03,} \mathrm{H05,} \mathrm{H08}$ & $1.000(0.272)$ & $0.00693(0.00231)$ \\
\hline Total & 15 & 3 & $0.448(0.134)$ & $0.00247(0.00320)$ \\
\hline
\end{tabular}

All mtDNA haplotypes were identified as a unique arrangement of nucleotides in the cytochrome b DNA sequence of individuals. Haplotype diversity and nucleotide diversity were calculated for the Lake Macquarie and Forster regions. Haplotype diversity (h) gave the probability that two randomly sampled alleles would be different (probability $0-1$ ), while nucleotide diversity $(\pi)$ determined whether the differences between 
haplotypes were minor (approaching zero) or major (approaching 1). Both h and $\pi$ were calculated in DnaSP $\vee 5.10$ (Librado and Rozas 2009). A median-joining network was constructed in PopART to visualise relationships among haplotypes (Bandelt et al. 1999).

\section{Nuclear DNA: SNPs}

Squirrel glider genomic DNA samples were examined on 1\% agarose gel electrophoresis and a NanoDrop 2000 Spectrophotometer (Thermo Scientific) to identify samples with appropriate concentration and purity for next-generation sequencing. The buccal swab genomic DNA samples did not pass this quality control stage; therefore 96 tissue DNA samples (belonging to 89 squirrel glider individuals) were selected for sequencing, all from within the Lake Macquarie LGA.

Genomic DNA was plated and sent to Diversity Arrays Technology (DArTseq), University of Canberra, Australia, for concentration and sequencing (Kilian et al. 2012). DArTseq is a high throughput method that combines genome complexity reduction methods and nextgeneration sequencing to detect a large number of SNPs at a relatively low cost (Kilian et al. 2012). Additionally, DArTseq optimises the technology for each species by selecting the most appropriate complexity reduction method. For this squirrel glider study, the Pstl-Sphl method was used prior to PCR amplification and sequencing of fragments on an Illumina Hiseq2500. This Pstl-Sphl restriction enzyme combination has proved extremely efficient in detecting SNPs in Australian marsupials (Schultz et al. 2018; Kjeldsen et al. 2019; Wright et al. 2019), including sugar gliders (Petaurus breviceps) (Knipler et al. 2021). For further details about the DArTseq process, please refer to Kilian et al. (2012).

DArTseq aligned the squirrel glider sequences to the Leadbeaters possum (Gymnobelideus leadbeateri) reference genome and retained SNPs with a minimum sequence identity of $70 \%$. Calling quality was assured with a high average read depth per locus (over 20 reads per locus average across all markers). Following this, SNPs and individuals were filtered using dartR 1.1.11 (Gruber et al. 2018) in R 4.0.2 (R Core Team 2015).. Duplicate individuals of lower quality were removed from the dataset. Loci were removed if the call rate was $<0.95$, if they had reproducibility $<0.99$, and if the hamming distance was $<0.2$. Loci were also removed if they deviated from Hardy-Weinberg Equilibrium ( $p<$ 0.05 ) and the SNP data set was analysed to ensure no monomorphic loci or linked loci remained. The final filtered dataset was used for all genomic analyses $(6,812$ SNPs retained).

All subsequent population genomic analyses were undertaken in R 4.0.2 (R Core Team 2015) unless otherwise stated. Observed and expected heterozygosity was calculated for each location to gain insight into the genetic diversity of squirrel glider populations. Observed heterozygosity $\left(\mathrm{H}_{\mathrm{obs}}\right)$ was calculated with the R package dartR, while expected heterozygosity $\left(\mathrm{H}_{\mathrm{ex}}\right)$ was calculated with the package adegenet 2.1.3 (Jombart 2008). The inbreeding coefficient was also calculated for each squirrel glider location $\left(\mathrm{F}_{\mathrm{IS}}=\left(\mathrm{H}_{\mathrm{ex}}-\mathrm{H}_{\mathrm{obs}}\right) / \mathrm{H}_{\mathrm{ex}}\right)$, and the average $F_{I S}$ and $F_{S T}$ were calculated for the overall region.

An Analysis of Molecular Variance (AMOVA) examined structure and population differentiation of squirrel gliders in Lake Macquarie while a Principal Coordinate Analysis (PCoA) was plotted to assist with the visualisation of this genetic structure. The AMOVA was run with the $\mathrm{R}$ package poppr 2.9.0 using 9,999 permutations (Zhian Kamvar 2021), while the PCoA was conducted in dartR. Next, genetic differentiation was examined in the form of pairwise $F_{S T}$ between the 14 locations of squirrel gliders. Pairwise $F_{S T}$ values were generated with the package dartR and 100 bootstraps were performed across loci to generate the corresponding p-values.

Squirrel glider genetic structure was examined further with STRUCTURE 2.3.4 (Pritchard et al. 2000). STRUCTURE uses a Bayesian clustering approach to assign individuals to groups ("K") where members display similar patterns of genetic variation. These groups are indicative of ancestral populations that individuals may have originated from (Pritchard et al. 2000; Pritchard et al. 2003). The analysis was run eight times for each K value (1-15) with a 10,000-length burn-in period and 10,000 Monte Carlo Markov Chain replications. The most likely K values were selected after viewing the results in Structure Harvester (Web v0.6.94) and referring to the Evanno method and the largest Delta $\mathrm{K}$ value (Evanno et al. 2005; Earl and VonHoldt 2012). Results were plotted in R.

\section{Landscape genomic analyses}

In addition to identifying genetic differentiation and genetic structure, we wanted to identify landscape features that influenced (diverting, preventing, or enhancing) squirrel glider gene flow in areas of the Lake Macquarie LGA. Genomic data was combined with spatially-explicit data to investigate the effect of geographic distance and habitat heterogeneity on genetic distance of squirrel glider populations. First, an isolation-by-distance (IBD) analysis was undertaken in the dartR package using 9,999 permutations. This mantel test took the log of the straight-line Euclidean distances between pairwise populations and compared them to the genetic distance matrix of populations in the form of $\mathrm{F}_{\mathrm{ST}} /\left(1-\mathrm{F}_{\mathrm{ST}}\right)$, to see if there was a significant relationship between geographic distance and genetic distance of populations. The results of this IBD analysis were used as a baseline, to which least cost path analyses were run to determine whether they could explain more of the genetic variation in the landscape. 
We run two separate least cost path (LCP) analyses using the gl.genleastcost function in the dartR package. LCP approach estimates the shortest distance between target core areas while accounting for resistance to movement (inferred here from the genetic data) (Adriaensen et al. 2003). LCP requires an input resistance surface, also called a friction matrix, and that is a spatial layer reflecting the degree to which a location in the landscape facilitates or impedes movement of a focal species (Zeller et al. 2012).

We created two friction matrices in ARCMAP 10.7.1 (ESRI, California) for each LCP scenario. The first friction matrix only considered water as biogeographical barriers. Hence, the Lake Macquarie and the Pacific Ocean were manually assigned "NoData" cell values, while all terrestrial areas were given a cell value of 1 , assuming constant movement capacity across a homogeneous terrestrial landscape within our study area. This analysis will be hereon referred to as an isolation by barrier analysis.

The second friction used the Plant Community Type (PCT) spatial layers from Bell et al. (2016) and Eco Logical Australia Pty Ltd (2003), and land use spatial layers from the NSW Government (2007). We assigned values to the cells (pixels in the map) based on our opinion, the literature, and a range of test models we ran. Values scaled from 1 for optimal habitat that eased dispersal, to 200 for unsuitable habitat that would render dispersal difficult. We divided vegetation layers into five categories based on the diet and habitat requirements of squirrel gliders (Smith 2002; Smith and Murray 2003; Ball et al. 2009; Niche Environment and Heritage 2013; Payne 2016): highly suitable vegetation (1), suitable vegetation (10), moderately suitable vegetation (20), moderately unsuitable vegetation (75) and unsuitable vegetation (100). Appendix 1 detailed how the 62 PCTs were assigned. Land use was divided into the following classes: Urban residential (80), roads (100), railways (80), rural residential without agriculture (70), rural residential with agriculture (100), native/exotic pasture matrix (100), grazing irrigated modified pastures (100), irrigated turf farming (100), mines/quarries and large cleared areas (200), the Lake and Ocean (NoData, aka complete barrier to dispersal). Highly suitable vegetation was given a 35-meter buffer so that two patches either side of a barrier (road/river etc.) would intersect within maximum gliding distance (70 meters (Van der Ree and Bennett 2003)), indicating crossing potential. If cells overlapped between vegetation and land use, then the minimum value was selected for the final friction matrix. This analysis will be heron referred to as a land cover analysis.

New geographic distances were calculated using the two friction matrixes (isolation by barrier raster and the least cost path raster, cell factor $=15$, function $=$ mean) and the spatial coordinates of individuals. These new pairwise geographic distances were then tested for correlation with genetic distances and number of neighbours $=8$. The statistics from each spatial analysis (IBD, isolation by barrier analysis and least cost path analysis) were then compared to find the best fit (Milanesi et al. 2016).

\section{Results}

\section{Trapping}

Squirrel gliders were trapped in 14 out of the 32 sites surveyed. We collected ear tissue samples from 94 squirrel glider individuals (Table 1), while an additional 30 squirrel gliders had buccal swab samples collected (Table 2). Many male and female squirrel gliders were caught over consecutive years in the original location they were trapped, suggesting they have site fidelity. For example, a male and female squirrel glider were recaught after two years within 50 meters of their original detection at location RA, and a male squirrel glider was recaught after two years within 100 meters of its original detection at location GSCA. Additionally, one adult male and one adult female squirrel glider were caught on either side of a 30-meter powerline easement during one week of live trapping (location WR).

\section{Cytochrome b}

Of the 70 squirrel gliders sequenced, nine polymorphic sites were identified (2.34\%), 376 conserved sites (97.66\%) and eight haplotypes. The average total nucleotide diversity was low for both Lake Macquarie LGA and Forster (Lake Macquarie $\pi=0.002 \pm$ SD 0.000, Forster $\pi=0.002$ \pm SD 0.003) and total haplotype diversity was moderately high for Lake Macquarie LGA ( $h=0.648 \pm$ SD 0.052$)$ but lower in Forster ( $h=0.448$, \pm SD 0.134). A star-like haplotype network was produced indicating a recent genetic bottleneck (Fig. 2). A BLASTn search of GenBank failed to find a match for haplotypes H02 (habitat fragment MP, refer Table 2), H04 (locations RHL, GSCA, OCN, SP, WYB) and H07 (habitat fragment MP, refer Table 2), therefore these haplotypes are believed to be unique to this study.

Haplotype three (H03) was the most common, occurring in $57.14 \%$ of individuals and most of the locations (Table 2 ). In comparison, haplotype eight (H08) was only observed once and it was unique to Forster's TUN location. Haplotypes two (H02) and seven (H07) were unique to one location at Lake Macquarie (MP). Locations SP and OR had a single haplotype at each site (Table 2). The average total nucleotide diversity was low for both regions (Lake Macquarie $\pi=0.00232 \pm$ SD 0.00034 , Forster $\pi=0.00247 \pm$ SD 0.00320 ) and total haplotype diversity was moderately high for Lake Macquarie ( $h=0.648 \pm$ SD 0.052) but lower for Forster ( $h=0.448, \pm$ SD 0.134 ).

\section{Genetic differentiation and structure}

Page $7 / 21$ 
DArTseq returned 22,579 loci from 92 squirrel glider samples and 14 locations in the Lake Macquarie LGA. Four squirrel glider samples did not meet quality control standards and were excluded. During the final filtering stage in $\mathrm{R}$, five duplicate squirrel glider samples were removed. Stringent filtering left 6,812 loci from 87 squirrel glider individuals and 14 locations in the Lake Macquarie LGA (Table 1). This dataset was used in subsequent analyses.

Firstly, observed heterozygosity was compared to expected heterozygosity at each location, to understand the levels of squirrel glider genetic diversity. Observed heterozygosity was higher than expected heterozygosity at every single location, however the values were low indicating low levels of genetic variability (Table 1 ). There was no evidence of inbreeding (average FIS $=-0.261$ ). An AMOVA examined the genetic variation of squirrel glider populations. The results showed that $84.5 \%$ of the genetic variation was contained within squirrel glider samples while $15.3 \%$ of the genetic variation was observed between populations, and $0.2 \%$ of the genetic variation was observed between samples within populations (Fig. 3). The cumulative percentage of genetic variation explained by the first four axes was $23.2 \%$, with axis 1 accounting for $8.6 \%$ of the variation (Fig. 3). The most important observations were that the southwestern squirrel glider populations (OR, SP, WR, WYB, WYC) separate out from the northeastern populations on axis 1, while FERNN and OCN each appear to separate out on axis 2.

Genetic differentiation of squirrel glider populations were compared in the form of pairwise $F_{S T}$. Statistically significant pairwise $F_{S T}$ values ranged from 0.015 (DUD vs RHL) to 0.335 (CROB vs SP) (Table 3). $\mathrm{F}_{\mathrm{ST}}$ values greater than 0.15 are indicative of significant differentiation and genetic structure (Frankham et al. 2002), and in this case many of the pairwise comparisons produced results that indicated considerable differentiation (Table 3). Squirrel gliders at location OR were greatly differentiated from all other areas $\left(F_{S T} 0.151\right.$ to 0.276$)$, and CROB, FERNN, OCN and SP displayed substantial genetic differentiation from most other areas (Table 3). As a result, the average $F_{S T}$ was quite high with a value of 0.149 .

Table 3. Pairwise $F_{S T}$ values between squirrel glider sampling locations (aka putative populations) are shown below the diagonal. Results generated from dataset of 6,812 SNPs and 87 individuals.

\begin{tabular}{|lllllllllllllll|}
\hline POP & CROB & DUD & FERNN & FERNS & GMP & GSCA & OCN & OR & RA & RHL & SP & WR & WYB & WYC \\
\hline CROB & - & NA & NA & NA & NA & NA & NA & NA & NA & NA & NA & NA & NA & NA \\
\hline DUD & 0.136 & - & NA & NA & NA & NA & NA & NA & NA & NA & NA & NA & NA & NA \\
\hline FERNN & 0.212 & 0.115 & - & NA & NA & NA & NA & NA & NA & NA & NA & NA & NA & NA \\
\hline FERNS & 0.233 & $0.004 *$ & 0.155 & - & NA & NA & NA & NA & NA & NA & NA & NA & NA & NA \\
\hline GMP & 0.197 & 0.108 & 0.201 & 0.137 & - & NA & NA & NA & NA & NA & NA & NA & NA & NA \\
\hline GSCA & 0.144 & 0.028 & 0.143 & 0.085 & 0.142 & - & NA & NA & NA & NA & NA & NA & NA & NA \\
\hline OCN & 0.191 & 0.119 & 0.181 & 0.083 & 0.180 & 0.131 & - & NA & NA & NA & NA & NA & NA & NA \\
\hline OR & 0.276 & 0.195 & 0.260 & 0.249 & 0.240 & 0.206 & 0.249 & - & NA & NA & NA & NA & NA & NA \\
\hline RA & 0.132 & 0.051 & 0.172 & 0.036 & 0.117 & 0.108 & 0.158 & 0.222 & - & NA & NA & NA & NA & NA \\
\hline RHL & 0.126 & 0.015 & 0.103 & 0.045 & 0.117 & 0.059 & 0.097 & 0.192 & 0.074 & - & NA & NA & NA & NA \\
\hline SP & 0.335 & 0.111 & 0.262 & NaN & 0.204 & 0.188 & 0.253 & 0.260 & 0.130 & 0.159 & - & NA & NA & NA \\
\hline WR & 0.149 & 0.092 & 0.164 & 0.102 & 0.141 & 0.135 & 0.171 & 0.151 & 0.110 & 0.110 & 0.116 & - & NA & NA \\
\hline WYB & 0.187 & 0.105 & 0.195 & 0.133 & 0.167 & 0.148 & 0.202 & 0.184 & 0.128 & 0.130 & 0.117 & 0.095 & - & NA \\
\hline WYC & 0.183 & 0.101 & 0.211 & 0.099 & 0.167 & 0.164 & 0.209 & 0.198 & 0.130 & 0.140 & 0.091 & 0.105 & 0.087 & NA \\
\hline
\end{tabular}

*NOTE: $\mathrm{F}_{\mathrm{ST}}$ values in italics are not significant according to the method proposed by Wright (1949) and updated by Weir and Cockerham (1984) $(p>0.05)$.

STRUCTURE analyses provided further insight into the genetic structure of squirrel gliders in the Lake Macquarie LGA. The Structure Harvester results showed that Delta $\mathrm{K}$ had a peak at $\mathrm{K}=2$, with a small peak again at $\mathrm{K}=6$ (Fig. 4). Results for both will be presented here since there can be bias towards finding $\mathrm{K}=2$ with the Delta $\mathrm{K}$ method (Cullingham et al. 2020). Upon visualising the $\mathrm{K}=2 \mathrm{STRUCTURE}$ admixture plot, it was clear that the squirrel glider individuals were divided into two clusters, similar to the results on axis 1 of the PCoA plot (populations northeast of the lake and populations southwest of the lake) (Fig. 5). When $\mathrm{K}=6$, unique clusters appeared within the FERNN, 
OCN, OR, and WR populations, suggesting that the Lake Macquarie individuals could have been derived from six squirrel glider ancestral sources (Fig. 5). Admixture was present in all sampling locations; however, some individuals were pure to clusters within FERNN, GSCA, OCN, OR and WR (q value $>0.8$ ).

\section{Spatial analyses}

An isolation by distance analysis determined whether there was a relationship between geographic straight-line distances and genetic distances of squirrel glider populations. The result was significant $\left(R^{2}=0.3227, p=0.01\right)($ Table 4$)$. Next, an isolation by barrier analysis accounted for biogeographic barriers (Lake Macquarie and the Pacific Ocean) to see if this explained more of the genetic variation. The $\mathrm{R}^{2}$ value did improve $\left(R^{2}=0.5390, p=0.001\right)$ (Table 4$)$, but it did not consider habitat heterogeneity. Thirdly, a least cost path analysis was run to include landscape features and habitat heterogeneity (biogeographical barriers, vegetation and land use). When run, it was clear that the least cost paths between populations (Fig. 6) explained the greatest proportion of genetic variation between populations $\left(R^{2}=0.6467, p=0.001\right)$ (Table 4).

Table 4

Analyses used to determine the relationship between different geographic distances and genetic distances between squirrel glider populations. Out of all the models below, the distances between populations generated by the least cost path model explained the greatest proportion of the genetic variation between populations.

\begin{tabular}{|llcc|}
\hline Analysis & Details & $\mathbf{R}^{2}$ value & P value \\
\hline Isolation by distance & Straight line distance & 0.3227 & 0.01 \\
\hline Isolation by barrier & Avoids lake and ocean & 0.5390 & 0.001 \\
\hline Least cost path & Considers land use, vegetation type and biogeographical barriers & 0.6467 & 0.001 \\
\hline
\end{tabular}

As a result of the least cost path analysis, thin vegetation corridors were identified as possible corridors to enhance squirrel glider gene flow. They include vegetation strips in the following locations: Fishery Point Road (Bonnells Bay), Kilaben Bay (Rathmines), Fernleigh Track (Whitebridge), vegetation west of Fernleigh Tack (Charlestown), Pacific Highway crossing (Jewells to Bennetts Green), vegetation patches between Glenrock State Conservation Area (Highfields) and Blackbutt Nature Reserve (New Lambton), and vegetation along creek lines (Fig. 7). Locations OR and SP are situated in heavily urbanised areas and additionally located on isolated peninsulas within the lake, so they were also identified as areas of conservation concern.

\section{Discussion}

Habitat fragmentation was identified as the main threat for the squirrel glider, particularly in the Central Coast of NSW (Woinarski et al. 2014). In this study, we examined whether the effects of habitat fragmentation were detectable on the populations genetic structure. We expected that squirrel gliders in isolated patches would have low levels of genetic diversity and limited gene flow. We also sought to identify areas that would enhance gene flow between populations in our study area and identify areas that present potential barriers to dispersal.

Our first hypothesis was partly rejected as we detected high haplotype diversity in squirrel glider populations, despite previous research recording low haplotype diversity in squirrel glider populations $40 \mathrm{~km}$ from Lake Macquarie in Port Stephen ( $\mathrm{h}=0.18)$, and $20 \mathrm{~km}$ from Lake Macquarie in Warnervale $(\mathrm{h}=0.50)$ (Pavlova et al. 2010). MtDNA has a relatively fast mutation rate and is useful for determining the genetic history of populations (Arif et al. 2011). High haplotype diversity and low nucleotide diversity in the Lake Macquarie squirrel glider population points to a historical genetic bottleneck followed by rapid expansion and recovery from a small effective population size (Grant and Bowen 1998; Avise 2000). This is reflected in the star-like haplotype network, with many haplotypes branching from the dominant central H03 haplotype (high haplotype diversity) depicting minimal nucleotide differences (low nucleotide diversity).

We also used SNPs to examine whether the genetic diversity of squirrel gliders would be low in habitat patches within Lake Macquarie LGA. Low genetic diversity has been observed in arboreal mammal populations within fragmented landscapes such as the Siberian flying squirrel (Pteromys volans) (Lampila et al. 2009) and ringtail possum (Pseudocheirus peregrinus) (Lancaster et al. 2016). Despite these predictions, squirrel gliders displayed higher than expected levels of observed heterozygosity within the Lake Macquarie LGA and there was no evidence of inbreeding (FIS = -0.261). Higher than expected heterozygosity could potentially be explained by the genetic bottleneck detected with the mtDNA analyses, as bottlenecks lead to a quick loss in rare alleles while heterozygosity decreases slowly over time (Lampila et al. 2009). It could also be reflective of the high density and abundance of squirrel gliders in the area since Lake Macquarie LGA is known to contain the highest density in Australia (Smith 2002; Fallding 2015). Taken together, the data suggest that the impacts of urban fragmentation of the Lake Macquarie forest system has not yet produced a substantial loss of heterozygosity with the associated risks of loss of fitness due to

Page 9/21 
inbreeding effects (Frankham et al. 2002). Nevertheless, heterozygosity values were quite low and restriction of squirrel gliders to smaller and more isolated habitat fragments may be expected to produce a drastic effect in coming generations.

Genetic differentiation (i.e. structure) between fragments was predicted to be quite high due to isolation by both the lake and extensive urbanisation. This expectation was based on the fact that squirrel gliders are sensitive to noise pollution in the urban matrix (Francis et al. 2015) and have a maximum glide distance of 70 meters (Van der Ree and Bennett 2003). This theory was supported with evidence of high levels of genetic structuring in the Lake Macquarie squirrel glider populations. The $\mathrm{F}_{\mathrm{ST}}$ values were unusually high considering the fine scale of this study, and they were significantly higher than sugar glider populations in the same study area. Knipler et al. (2021) used 11,292 SNPs to examine the population structure of sugar gliders in the Lake Macquarie LGA and the pairwise $F_{S T}$ values ranged from 0.011 to 0.131 . Despite the two species sharing similar life history traits and requiring similar habitat (Lindenmayer 2002), the difference was considerable (squirrel glider $\mathrm{F}_{\mathrm{ST}}$ values from 0.015 to 0.335). For example, in the present study there was a high level of genetic differentiation between squirrel gliders at locations OR and WR $\left(F_{S T}=0.151\right)$, but in Knipler et al. (2021) the $F_{S T}$ value for sugar gliders between OR and WR was significantly lower $\left(F_{S T}=0.042\right)$. Squirrel gliders had greater pairwise $F_{S T}$ values for every location where squirrel gliders and sugar gliders were present together (OR, SP, WR, WYB, WYC) (Knipler et al. 2021). It is possible that squirrel gliders are more specialised and sensitive to the urban matrix and that is why they are experiencing higher levels of differentiation than sugar gliders. This warrants further investigation. Population differentiation is characteristic of most specialist, arboreal mammals in fragmented habitats (Barratt et al. 1999; Larsen et al. 2013; Baden et al. 2014; Sgarlata et al. 2016).

While there was an isolation-by-distance pattern of gene flow in the Lake Macquarie LGA squirrel glider populations, it didn't explain a large proportion of the genetic variation. Microsatellite analyses by Goldingay et al. (2013) for squirrel glider populations in the cities of Mackay and Brisbane, Queensland, found no isolation-by-distance effect, with strong genetic divergence occurring in squirrel glider populations 3 km apart after 30 years of landscape change. Goldingay et al. (2013) suggests that genetic drift in habitat fragments can have a stronger effect on allele frequencies than geographic distance. In the Lake Macquarie LGA, there was evidence of significant genetic differentiation between squirrel glider locations that were geographically close to each other. For example, high levels of genetic differentiation were detected between two locations that were only $1.8 \mathrm{~km}$ apart but divided by urban development in the town Whitebridge (FERNN and OCN $\left.F_{S T}=0.181\right)$, and locations 900 meters apart but divided by urban development in the town Valentine (CROB and RA F ST $=0.132)$. This contrasts with squirrel glider samples that were collected $2.2 \mathrm{~km}$ and $1.5 \mathrm{~km}$ from each other but connected by forest $($ WYB and WYC F $=0.087$, DUD and GSCA $F_{S T}=0.028$ ). This is where the landscape genetic analyses proved useful. By combining next-generation sequencing and landscape genetic analyses this study was able to explain a large portion of the genetic variation observed in the squirrel glider populations. Only one other study has used resistance models and least cost path analyses to infer genetic structure of squirrel gliders in the past, and the proportion of variation explained by their model was only $\mathrm{R}^{2}=0.027$ (Dudaniec et al. 2016), in comparison to the current study where $\mathrm{R}^{2}=$ 0.647. A possible reason for this improvement is the incorporation of genome-wide SNPs rather than microsatellites, and the use of a 35meter buffer to account for the maximum glide distance of 70 meters (Van der Ree and Bennett 2003).

Corridors that could potentially enhance gene flow were identified on the basis of genetic data. Landscape genomics is a rapidly growing field that presents tremendous potential to estimate functional connectivity (Balkenhol et al. 2017). Genetically derived connectivity estimates reflect past landscape permeability due to the time it takes to detect barriers (Cushman et al. 2013), and hence does not necessarily detect current gene flow in a rapidly evolving landscape such as Lake Macquarie LGA. Furthermore, genetic data do not directly convey how animals move through the landscape. Hence, for conservation purposes, it is often recommended to complement connectivity analyses with other sets of empirical data. Movement data in particular enable to measure unambiguously how animals respond to landscape features as they are moving (Cushman 2013), and would provide a more complete picture of the resources needed by squirrel gliders as they cope with habitat change.

This study not only identified corridors, but it also investigated possible barriers to dispersal. In this study a 30-meter-wide powerline easement and the corresponding fragmentation of habitat did not impact squirrel glider dispersal in location WR. However, Holt and Brady (2011) have reported the reluctance of female Mahogany gliders (Petaurus gracilis) to cross 30-meter powerline easements, so further research is needed to confirm that the crossing observed by a female squirrel glider in this study is not an anomaly. Additionally, the power poles at WR were wooden and attention should be given to areas that use metal power poles, as the squirrel gliders in this study may have been using the wooden poles as steppingstones across the landscape. It is not only powerlines that create gaps between habitat patches; roads create obstacles as well. Sections of The Pacific Highway in the northeast area of Lake Macquarie LGA have mature trees in the median strip which is extremely valuable for the gene flow of squirrel glider populations on either side (e.g. the town Bennetts Green). These trees should be conserved since Van der Ree et al. (2010) radio tracked squirrel gliders and found 67\% of them crossed highways when trees were in the median strip, while only $6 \%$ (one male) crossed a highway when there were no trees (Van der Ree et al. 2010). Squirrel gliders were not caught in trapping locations west of the Pacific Motorway, so this study was unable to gain insight into the genetic effects of the Pacific

Page 10/21 
Motorway on squirrel glider populations. Despite this, sugar glider populations experienced genetic differentiation because of the Motorway (Knipler et al. 2021), and since squirrel gliders have experienced higher levels of genetic structure in the Lake Macquarie LGA then they may also be experiencing genetic differentiation on either side of this road, especially since there are no mature trees in the median strip. Structures such as glider poles (Ball and Goldingay 2008; Goldingay et al. 2019) should therefore be installed to assist the gene flow of sugar gliders, which would also help the squirrel gliders that inhabit the same area.

We here used LCP to estimate functional connectivity, which assumes animals have perfect knowledge of the landscape, and therefore move across the landscape in an optimal way. In contrast, circuit-theory connectivity is based on random walk and apply concepts related to flow of charge through an electrical circuit to the movement of individuals through a landscape. The output of such models is the probability of movement across each pixel of the landscape and incorporates all possible pathways across the area studied (McRae et al. 2008). Since it is likely that squirrel gliders do not have a complete knowledge of their surroundings when dispersing, corridors identified through circuit theory may differ from and complement those we identified through LCP.

Continued fragmentation is the greatest risk to squirrel gliders in our study area, particularly as the effects of urbanisation are exacerbated by the biogeographical barrier of the lake. Conservation of remaining habitat should be a priority for the squirrel gliders in this area. Thin remnant corridors need to be conserved to promote gene flow and connectivity of squirrel glider populations in the urban matrix. If unsuccessful, squirrel glider populations may experience further isolation which could in turn lead to a loss of genetic diversity through genetic drift. The Lake Macquarie LGA is a stronghold for the threatened species in Australia, and as such this location warrants priority conservation management. High levels of genetic structure and population differentiation also warrants proactive conservation management in response. Considering the difficulty in collecting large sample sizes of threatened species, the use of genome-wide SNPs, as we have undertaken, has allowed a thorough investigation into the fine-scale structure of squirrel gliders in the Lake Macquarie LGA from which data driven conservation management decisions can be made.

\section{Declarations}

Conflicts of interest/Competing interests: The authors declare no competing interest.

Funding: Lake Macquarie City Council, Environmental Grants (2018-2020); UOW Centre for Sustainable Ecosystem Solutions, research student support grant (2020), Paddy Pallin Research Grant from the Royal Zoological Society of New South Wales

Availability of data and material: DArTseq data and mtDNA sequences are available from the authors upon request.

Author contribution: Monica Knipler, Mark Dowton, John Clulow and Katarina Mikac contributed to the study conception and design. Material preparation and sample collection were performed by Monica Knipler and Ninon Meyer, and analyses were performed by Monica Knipler with advice from Mark Dowton and Katarina Mikac. The first draft of the manuscript was written by Monica Knipler and all authors commented on previous versions of the manuscript. All authors read and approved the final manuscript.

Code availability: Not applicable.

Animal research (ethics): Squirrel glider genetic samples were collected under University of Wollongong Animal Ethics permits AE15/11 and AE19/02 and NSW Scientific License SL101587 and SL101968, the University of Newcastle Animal Care and Ethics Committee (A-2015-510), and NSW Scientific License SL100190.

Consent to participate (ethics): Not applicable.

Consent for publication: All authors consent to the submission of this article to Conservation Genetics.

\section{References}

1. Adriaensen, F., Chardon, J. P., De Blust, G., Swinnen, E., Villalba, S., Gulinck, H., and Matthysen, E. (2003). The application of 'least-cost' modelling as a functional landscape model. Landscape and Urban Planning 64, 233-247. doi:10.1016/S0169-2046(02)00242-6

2. Arif, I. A., Khan, H. A., Bahkali, A. H., Al Homaidan, A. A., Al Farhan, A. H., Al Sadoon, M., and Shobrak, M. (2011). DNA marker technology for wildlife conservation. Saudi Journal of Biological Sciences 18, 219-225. doi:10.1016/j.sjbs.2011.03.002

3. Avise, J. C. (2000). 'Phylogeography: the history and formation of species'. (Harvard University Press: Cambridge.)

4. Baden, A. L., Holmes, S. M., Johnson, S. E., Engberg, S. E., Louis, E. E., and Bradley, B. J. (2014). Species-level view of population structure and gene flow for a critically endangered primate (Varecia variegata). Ecology and Evolution 4, 2675-2692. doi:10.1002/ece3.1119

Page 11/21 
5. Balkenhol, N., Cushman, S. A., Storfer, A. T., and Waits, L. P. (2015). Introduction to Landscape Genetics - Concepts, Methods, Applications. Landscape Genetics: Concepts, Methods, Applications, 1-8. doi:10.1002/9781118525258.ch01

6. Balkenhol, N., Dudaniec, R. Y., Krutovsky, K. V., Johnson, J. S., Cairns, D. M., Segelbacher, G., Selkoe, K. A., von der Heyden, S., Wang, I. J., Selmoni, O., and Joost, S. (2017). Landscape Genomics: Understanding Relationships Between Environmental Heterogeneity and Genomic Characteristics of Populations. In pp. 261-322. (Springer, Cham.) doi:10.1007/13836_2017_2

7. Ball, T., Adams, E., and Goldingay, R. L. (2009). Diet of the squirrel glider in a fragmented landscape near Mackay, central Queensland. Australian Journal of Zoology 57, 295-304. doi:10.1071/Z008095

8. Ball, T. M., and Goldingay, R. L. (2008). Can wooden poles be used to reconnect habitat for a gliding mammal? Landscape and Urban Planning 87, 140-146. doi:10.1016/j.landurbplan.2008.05.007

9. Bandelt, H. J., Forster, P., and Rohl, A. (1999). Median-joining networks for inferring intraspecific phylogenies. Molecular Biology and Evolution 16, 37-48. doi:10.1093/oxfordjournals.molbev.a026036

10. Barratt, E. M., Gurnell, J., Malarky, G., Deaville, R., and Bruford, M. W. (1999). Genetic structure of fragmented populations of red squirrel (Sciurus vulgaris) in the UK. Molecular ecology 8, 55-63. doi:10.1046/j.1365-294X.1999.00771.X

11. Bell, S., Driscoll, C., and Survey, E. F. (2016). Volume 1: Vegetation Mapping Report, Lake Macquarie Local Government Area Stages 1 - 6.

12. Bradshaw, C. J. A. (2012). Little left to lose: Deforestation and forest degradation in Australia since European colonization. Journal of Plant Ecology 5, 109-120. doi:10.1093/jpe/rtr038

13. Brearley, G., McAlpine, C., Bell, S., and Bradley, A. (2011). Squirrel glider home ranges near urban edges in eastern Australia. Journal of Zoology 285, 256-265. doi:10.1111/j.1469-7998.2011.00837.x

14. Brumfield, R. T., Beerli, P., Nickerson, D. A., and Edwards, S. V. (2003). The utility of single nucleotide polymorphisms in inferences of population history. Trends in Ecology \& Evolution 18, 249-256. doi:10.1016/S0169-5347(03)00018-1

15. Cullingham, C. I., Miller, J. M., Peery, R. M., Dupuis, J. R., Malenfant, R. M., Gorrell, J. C., and Janes, J. K. (2020). Confidently identifying the correct $\mathrm{K}$ value using the $\Delta \mathrm{K}$ method: When does $\mathrm{K}=2$ ? Molecular Ecology 29, 862-869. doi:10.1111/mec.15374

16. Cushman, S. A. (2013). Biological corridors and connectivity. In 'Key Topics in Conservation Biology 2'. pp. 384-404. (Wiley-Blackwell: Hoboken, NJ.)

17. Cushman, S. A., and Lewis, J. S. (2010). Movement behavior explains genetic differentiation in American black bears. Landscape Ecology 25, 1613-1625. doi:10.1007/s10980-010-9534-6

18. Dudaniec, R. Y., Worthington Wilmer, J., Hanson, J. O., Warren, M., Bell, S., and Rhodes, J. R. (2016). Dealing with uncertainty in landscape genetic resistance models: A case of three co-occurring marsupials. Molecular Ecology 25, 470-486. doi:10.1111/mec.13482

19. Dussex, N., Taylor, H. R., Stovall, W. R., Rutherford, K., Dodds, K. G., Clarke, S. M., and Gemmell, N. J. (2018). Reduced representation sequencing detects only subtle regional structure in a heavily exploited and rapidly recolonizing marine mammal species. Ecology and Evolution 8, 8736-8749. doi:10.1002/ece3.4411

20. Earl, D. A., and VonHoldt, B. M. (2012). STRUCTURE HARVESTER: A website and program for visualizing STRUCTURE output and implementing the Evanno method. Conservation Genetics Resources 4, 359-361. doi:10.1007/s12686-011-9548-7

21. Eco Logical Australia Pty Ltd (2003). Lower Hunter \& Central Coast Regional Biodiversity Conservation Strategy Technical Report 2003 Digital Aerial Photo Interpretation \& Updated Extant Vegetation Community Map.

22. Evanno, G., Regnaut, S., and Goudet, J. (2005). Detecting the number of clusters of individuals using the software structure: a simulation study. Molecular Ecology 14, 2611-2620. doi:10.1111/j.1365-294X.2005.02553.x

23. Fallding, M. (2015). Lake Macquarie Squirrel Glider Planning and Managing Guidelines 2015. (Lake Macquarie City Council, Lake Macquarie).

24. Francis, M. J., Spooner, P. G., and Matthews, A. (2015). The influence of urban encroachment on squirrel gliders (Petaurus norfolcensis): Effects of road density, light and noise pollution. Wildlife Research 42, 324-333. doi:10.1071/WR14182

25. Frankham, R., Ballou, J. D., and Briscoe, D. A. (2002). 'Introduction to Conservation Genetics'. (Cambridge University Press: Cambridge.) doi:10.1016/j.foreco.2003.12.001

26. Goldingay, R. L., Harrisson, K. A., Taylor, A. C., Ball, T. M., Sharpe, D. J., and Taylor, B. D. (2013). Fine-scale genetic response to landscape change in a gliding mammal. PLOS ONE 8, 1-10. doi:10.1371/journal.pone.0080383

27. Goldingay, R. L., and Sharpe, D. J. (2004). How do we conserve the squirrel glider in Brisbane's urban matrix? In 'Conservation of Australia's Forest Fauna '. pp. 663-677 Available at: http://publications.rzsnsw.org.au/doi/pdf/10.7882/FS.2004.038

28. Goldingay, R. L., Sharpe, D. J., and Dobson, M. D. J. (2010). Variation in the home-range size of the squirrel glider (Petaurus norfolcensis). Australian Mammalogy 32, 183-188. doi:10.1071/AM10006

Page 12/21 
29. Goldingay, R. L., and Taylor, B. D. (2009). Gliding performance and its relevance to gap crossing by the squirrel glider (Petaurus norfolcensis). Australian Journal of Zoology 57, 99-104. doi:10.1071/Z009003

30. Goldingay, R. L., Taylor, B. D., and Parkyn, J. L. (2019). Use of tall wooden poles by four species of gliding mammal provides further proof of concept for habitat restoration. Australian Mammalogy 41, 255. doi:10.1071/AM18008

31. Gracanin, A., Gracanin, V., and Mikac, K. M. (2019). The selfie trap: A novel camera trap design for accurate small mammal identification. Ecological Management and Restoration 20, 156-158. doi:10.1111/emr.12345

32. Grant, W. S., and Bowen, B. W. (1998). Shallow population histories in deep evolutionary lineages of marine fishes: Insights from sardines and anchovies and lessons for conservation. In 'Journal of Heredity'. pp. 415-426 doi:10.1093/jhered/89.5.415

33. Gruber, B., Unmack, P. J., Berry, O. F., and Georges, A. (2018). dartr: An r package to facilitate analysis of SNP data generated from reduced representation genome sequencing. Molecular Ecology Resources 18, 691-699. doi:10.1111/1755-0998.12745

34. Hall, T. A. (1999). BioEdit: a user-friendly biological sequence alignment editor and analysis program for Windows $95 / 98 / N T$. Nucleic Acids Symposium Series 41, 95-98. doi:citeulike-article-id:691774

35. Holt, S., and Brady, M. (2011). Mahogany Glider Management Plan for Ingham-Tully Transmission Line Upgrade DOCUMENT CONTROL SUMMARY REPORT AND CLIENT DETAILS Title: Mahogany Glider Management Plan for Ingham-Tully Transmission Line UpgradeAddendum Report Client: Powerlink Queensland. Available at: www.biotropica.com.au [accessed 16 May 2021]

36. Irwin, D. M., Kocher, T. D., and Wilson, A. C. (1991). Evolution of the cytochrome b gene of mammals. Journal of Molecular Evolution 32, 128-144. doi:10.1007/BF02515385

37. Jombart, T. (2008). Adegenet: A R package for the multivariate analysis of genetic markers. Bioinformatics 24, $1403-1405$. doi:10.1093/bioinformatics/btn129

38. Kilian, A., Wenzl, P., Huttner, E., Carling, J., Xia, L., Blois, H., Caig, V., Heller-Uszynska, K., Jaccoud, D., Hopper, C., Aschenbrenner-Kilian, M., Evers, M., Peng, K., Cayla, C., Hok, P., and Uszynski, G. (2012). Diversity arrays technology: A generic genome profiling technology on open platforms. Methods in Molecular Biology 888, 67-89. doi:10.1007/978-1-61779-870-2_5

39. Kjeldsen, S. R., Raadsma, H. W., Leigh, K. A., Tobey, J. R., Phalen, D., Krockenberger, A., Ellis, W. A., Hynes, E., Higgins, D. P., and Zenger, K. R. (2019). Genomic comparisons reveal biogeographic and anthropogenic impacts in the koala (Phascolarctos cinereus): a dietaryspecialist species distributed across heterogeneous environments. Heredity 122, 525-544. doi:10.1038/s41437-018-0144-4

40. Kjeldsen, S. R., Zenger, K. R., Leigh, K., Ellis, W., Tobey, J., Phalen, D., Melzer, A., FitzGibbon, S., and Raadsma, H. W. (2016). Genome-wide SNP loci reveal novel insights into koala (Phascolarctos cinereus) population variability across its range. Conservation Genetics 17 , 337-353. doi:10.1007/s10592-015-0784-3

41. Knipler, M., Dowton, M., and Mikac, K. (2021). A Major Highway Acts to Genetically Structure a Sugar Glider (Petaurus Breviceps) Population. Under Review. doi:10.21203/rs.3.rs-502078/v1

42. Kocher, T. D., Thomas, W. K., Meyer, A., Edwards, S. V., Paabo, S., Villablanca, F. X., Wilson, A. C., Pääbo, S., Villablanca, F. X., and Wilson, A. C. (1989). Dynamics of mitochondrial DNA evolution in animals: amplification and sequencing with conserved primers. Proceedings of the National Academy of Sciences of the United States of America 86, 6196-6200. doi:10.1073/pnas.86.16.6196

43. Kumar, S., Banks, T. W., and Cloutier, S. (2012). SNP Discovery through Next-Generation Sequencing and Its Applications. International journal of plant genomics 2012, 831460. doi:10.1155/2012/831460

44. Lah, L., Trense, D., Benke, H., Gunnlaugsson, P., Lockyer, C., Rk, A. O. “' Z., Rk, B. O. “' Z., Pawliczka, I., Roos, A., Siebert, U., Skó Ra 7 t, K., Víkingsson, G., and Tiedemann, R. (2016). Spatially Explicit Analysis of Genome-Wide SNPs Detects Subtle Population Structure in a Mobile Marine Mammal, the Harbor Porpoise. doi:10.1371/journal.pone.0162792

45. Lampila, S., Kvist, L., Wistbacka, R., and Orell, M. (2009). Genetic diversity and population differentiation in the endangered Siberian flying squirrel (Pteromys volans) in a fragmented landscape. European Journal of Wildlife Research 55, 397-406. doi:10.1007/s10344009-0259-2

46. Lancaster, M. L., Cooper, S. J. B., and Carthew, S. M. (2016). Genetic consequences of forest fragmentation by agricultural land in an arboreal marsupial. Landscape Ecology 31, 655-667. doi:10.1007/s10980-015-0271-8

47. Larsen, P. A., Marchán-Rivadeneira, M. R., and Baker, R. J. (2013). Speciation Dynamics of the Fruit-Eating Bats (Genus Artibeus): With Evidence of Ecological Divergence in Central American Populations. In 'Bat Evolution, Ecology, and Conservation'. pp. 315-339. (Springer New York: New York, NY.) doi:10.1007/978-1-4614-7397-8_16

48. Librado, P., and Rozas, J. (2009). DnaSP v5: A software for comprehensive analysis of DNA polymorphism data. Bioinformatics 25, 1451-1452. doi:10.1093/bioinformatics/btp187

49. Lindenmayer, D. (2002). 'Gliders of Australia : a natural history'. (UNSW Press.) Available at: https://openresearchrepository.anu.edu.au/handle/1885/92545 [accessed 16 August 2017]

Page $13 / 21$ 
50. Liu, N., Chen, L., Wang, S., Oh, C., and Zhao, H. (2005). Comparison of single-nucleotide polymorphisms and microsatellites in inference of population structure. BMC Genetics 6. doi:10.1186/1471-2156-6-S1-S26

51. Manel, S., Schwartz, M. K., Luikart, G., and Taberlet, P. (2003). Landscape genetics: Combining landscape ecology and population genetics. Trends in Ecology and Evolution 18, 189-197. doi:10.1016/S0169-5347(03)00008-9

52. Mawbey, R. (1989). A New Trap Design for the Capture of Sugar Gliders, Petaurus-Breviceps. Wildlife Research 16, 425-428.

53. McRae, B. H., Dickson, B. G., Keitt, T. H., and Shah, V. B. (2008). Using circuit theory to model connectivity in ecology, evolution, and conservation. Ecology 89, 2712-2724. doi:10.1890/07-1861.1

54. Milanesi, P., Holderegger, R., Caniglia, R., Fabbri, E., and Randi, E. (2016). Different habitat suitability models yield different least-cost path distances for landscape genetic analysis. Basic and Applied Ecology 17, 61-71. doi:10.1016/j.baae.2015.08.008

55. Niche Environment and Heritage (2013). Distribution, habitat and conservation of the Squirrel Glider near Forster, NSW. Parramatta Office: OEH.

56. NSW Government (2007). NSW Landuse 2007 - Data.NSW. Available at: https://data.nsw.gov.au/data/dataset/nswlanduseac11c/resource/e641e722-96c5-4519-874a-e148a496fac6?inner_span=True [accessed 6 May 2021]

57. NSW Office of Environment and Heritage (2021). BioNet Atlas. Available at: https://www.environment.nsw.gov.au/atlaspublicapp/ui_modules/atlas_/atlassearch.aspx

58. Pavlova, A., Walker, F. M., Van der Ree, R., Cesarini, S., and Taylor, A. C. (2010). Threatened populations of the Australian squirrel glider (Petaurus norfolcensis) show evidence of evolutionary distinctiveness on a Late Pleistocene timescale. Conservation Genetics 11, 23932407. doi:10.1007/s10592-010-0125-5

59. Payne, C. (2016). The effects of habitat fragmentation and vegetation type on forest structure and arboreal marsupial populations, with particular focus on the squirrel glider (Petaurus norfolcensis), in an urban landscape. Honours thesis, University of Wollongong, Wollongong NSW.

60. Pritchard, J. K., Stephens, M., and Donnelly, P. (2000). Inference of population structure using multilocus genotype data. Genetics 155, 945-59.

61. Pritchard, J., Wen, X., and Falush, D. (2003). Documentation for STRUCTURE software: version 2.3 | Request PDF. Available at: https://www.researchgate.net/publication/252278965_Documentation_for_STRUCTURE_software_version_23 [accessed 12 March 2021]

62. Quin, D. G. (1995). Population ecology of the squirrel glider (Petaurus norfolcensis) and the sugar glider (P. breviceps) (Maruspialia: Petauridae) at Limeburners Creek, on the central north coast of New South Wales. Wildlife Research 22, 471-505. doi:10.1071/WR9950471

63. R Core Team (2015). R: a language and environment for statistical computing. Available at: https://www.gbif.org/tool/81287/r-alanguage-and-environment-for-statistical-computing [accessed 1 April 2021]

64. Van der Ree, R. (2002). The population ecology of the squirrel glider (Petaurus norfolcensis) within a network of remnant linear habitats. Wildlife Research 29, 329-340. doi:10.1071/WR01095

65. Van der Ree, R., and Bennett, A. F. (2003). Home range of the squirrel glider (Petaurus norfolcensis) in a network of renant linear habitats. Journal of the Zoological Society of London 259, 327-336. doi:10.1017/s0952836902003229

66. Van der Ree, R., Bennett, A. F., and Gilmore, D. C. (2004). Gap-crossing by gliding marsupials: Thresholds for use of isolated woodland patches in an agricultural landscape. Biological Conservation 115, 241-249. doi:10.1016/S0006-3207(03)00142-3

67. Van der Ree, R., Cesarini, S., Sunnucks, P., Moore, J. L., and Taylor, A. (2010). Large gaps in canopy reduce road crossing by a gliding mammal. Ecology and Society 15. doi:35

68. Schultz, A. J., Cristescu, R. H., Littleford-Colquhoun, B. L., Jaccoud, D., and Frère, C. H. (2018). Fresh is best: Accurate SNP genotyping from koala scats. Ecology and evolution 8, 3139-3151. doi:10.1002/ece3.3765

69. Sgarlata, G. M., Salmona, J., Razanaparany, T. P., Joseph, C., Rabarivola, F. J., Rasolondraibe, E., Andriaholinirina, N., Lafosse, S., Chikhi, L., and Manni, F. and Bayart, F. (2016). Mitochondrial Genetic Diversity in the Crowned Sifaka (Propithecus coronatus) in a Fragmented Landscape. Primate Conservation 30, 39-57.

70. Sharma, S., Dutta, T., Maldonado, J. E., Wood, T. C., Panwar, H. S., and Seidensticker, J. (2013). Forest corridors maintain historical gene flow in a tiger metapopulation in the highlands of central India. Proceedings of the Royal Society B: Biological Sciences $\mathbf{2 8 0 .}$ doi:10.1098/rspb.2013.1506

71. Sharpe, D. (2004). 'Effect of flower failure on a population of squirrel gliders (Petaurus norfolcensis) in northeast New South Wales. In "The Biology of Australian Possums and Gliders". (Eds RL Goldingay \& SM Jackson)'. (Surrey Beatty: Sydney.)

72. Sharpe, D., and Goldingay, R. L. (2007). Home range of the Australian squirrel glider, Petaurus norfolcensis (Diprotontia). Journal of Mammalogy 88, 1515-1522. doi:10.1644/06-MAMM-A-404R1.1

Page $14 / 21$ 
73. Shi, W., Ayub, Q., Vermeulen, M., Shao, R. G., Zuniga, S., Van Der Gaag, K., De Knijff, P., Kayser, M., Xue, Y., and Tyler-Smith, C. (2010). A worldwide survey of human male demographic history based on Y-SNP and Y-STR data from the HGDP-CEPH populations. Molecular Biology and Evolution 27, 385-393. doi:10.1093/molbev/msp243

74. Smith, A. (2002). Squirrel Glider (Petaurus norfolcensis) Conservation Management Plan: Wyong Shire Prepared by Andrew Smith for Wyong Shire Council.

75. Smith, A. P., and Murray, M. (2003). Habitat requirements of the squirrel glider (Petaurus norfolcensis) and associated possums and gliders on the New South Wales central coast. Wildlife Research 30, 291-301. doi:10.1071/WR01115

76. Soanes, K., Vesk, P. A., and Van der Ree, R. (2015). Monitoring the use of road-crossing structures by arboreal marsupials: Insights gained from motion-triggered cameras and passive integrated transponder (PIT) tags. Wildlife Research 42, 241-256. doi:10.1071/WR14067

77. Taylor, A. C., Walker, F. M., Goldingay, R. L., Ball, T., and van der Ree, R. (2011). Degree of landscape fragmentation influences genetic isolation among populations of a gliding mammal. PLOS ONE 6. doi:10.1371/journal.pone.0026651

78. White, L. C., Moseby, K. E., Thomson, V. A., Donnellan, S. C., and Austin, J. J. (2018). Long-term genetic consequences of mammal reintroductions into an Australian conservation reserve. Biological Conservation 219, 1-11. doi:10.1016/j.biocon.2017.12.038

79. Winning, G. and King, J. (2008). A new trap design for capturing squirrel gliders and sugar gliders. Australian Mammology 29, $245-249$.

80. Woinarski, J., Burbidge, A. A., Harrison, P., and Commonwealth Scientific and Industrial Research Organization (Australia) (2014). 'The action plan for Australian mammals 2012'. (CSIRO publishing: Collingwood, VIC.)

81. Wright, B., Farquharson, K. A., McLennan, E. A., Belov, K., Hogg, C. J., and Grueber, C. E. (2019). From reference genomes to population genomics: Comparing three reference-aligned reduced-representation sequencing pipelines in two wildlife species. BMC Genomics 20, 453. doi:10.1186/s12864-019-5806-y

82. Zeller, K. A., McGarigal, K., and Whiteley, A. R. (2012). Estimating landscape resistance to movement: A review. Landscape Ecology 27, 777-797. doi:10.1007/s10980-012-9737-0

83. Zhian Kamvar, M. N. (2021). Package 'poppr' Type Package Title Genetic Analysis of Populations with Mixed Reproduction Encoding UTF-8 Depends $\mathrm{R}(>=2.15 .1)$, adegenet (>= 2.0.0). doi:10.7717/peerj.281

\section{Figures}




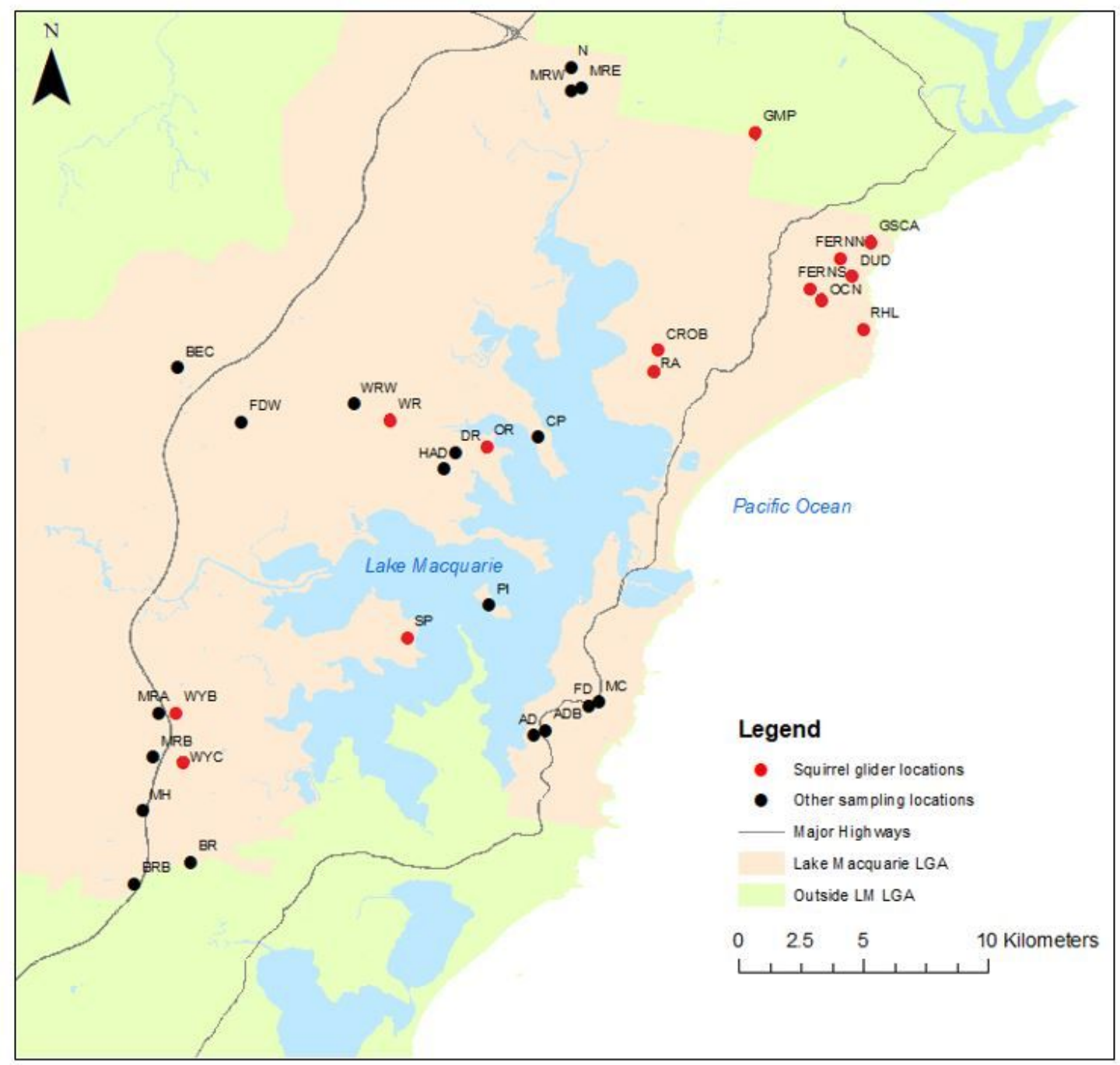

Figure 1

Squirrel glider trapping locations from 2017 - 2020. Red dots illustrate locations where squirrel gliders were caught. See Table 1 for numbers of individuals and location information. NOTE: PI (Pulbah Island) was only subject to camera trapping. No gliders were detected so trapping did not take place here. Note: The designations employed and the presentation of the material on this map do not imply the expression of any opinion whatsoever on the part of Research Square concerning the legal status of any country, territory, city or area or of its authorities, or concerning the delimitation of its frontiers or boundaries. This map has been provided by the authors. 


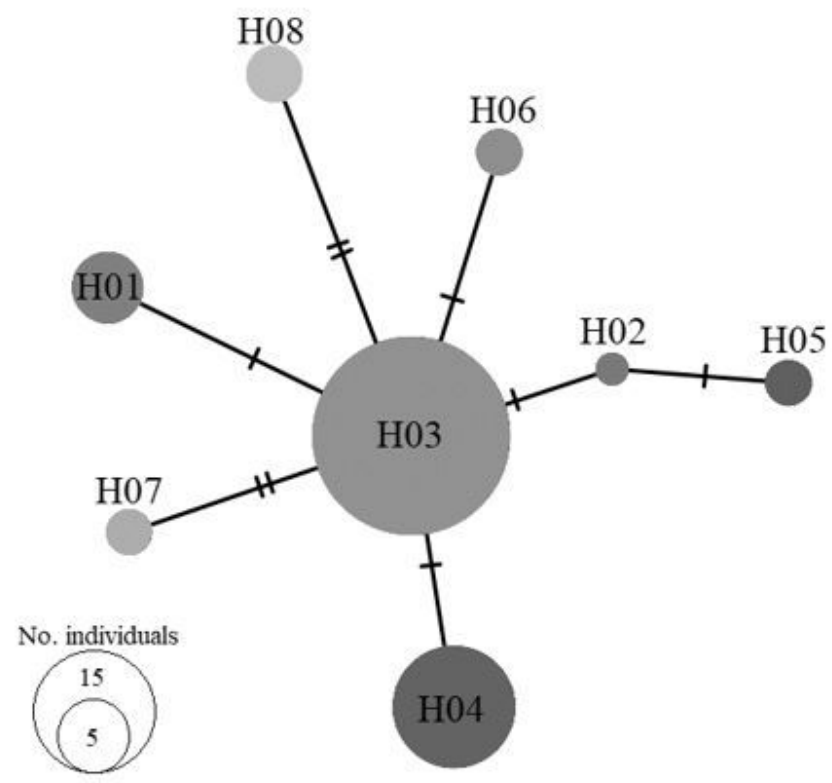

Figure 2

MtDNA median-joining network displaying the relationship among eight cytochrome b haplotypes (H01-H08) of squirrel gliders in Lake Macquarie and Forster, NSW. A slash in the branches linking two haplotypes indicate one nucleotide substitution and two slashes indicate two nucleotide substitutions. 

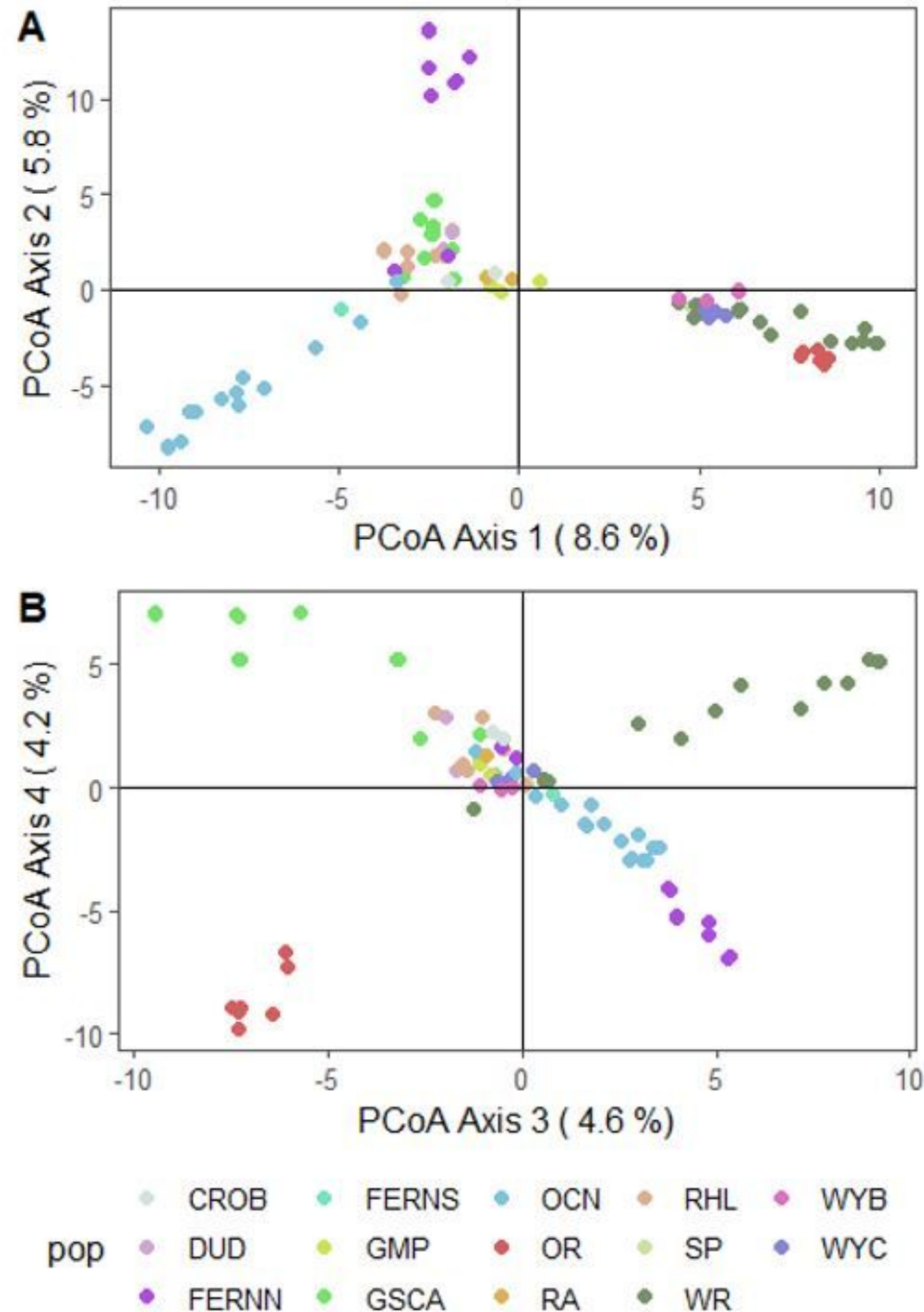

Figure 3

Principal Coordinates Analysis (PCoA) based on the genetic distances of squirrel gliders from 14 putative populations ("pop") and 6,812 loci. (A) Graphical representation of the first two PCoA axes. (B) Graphical representation of the third and fourth PCoA axes. N=87. 


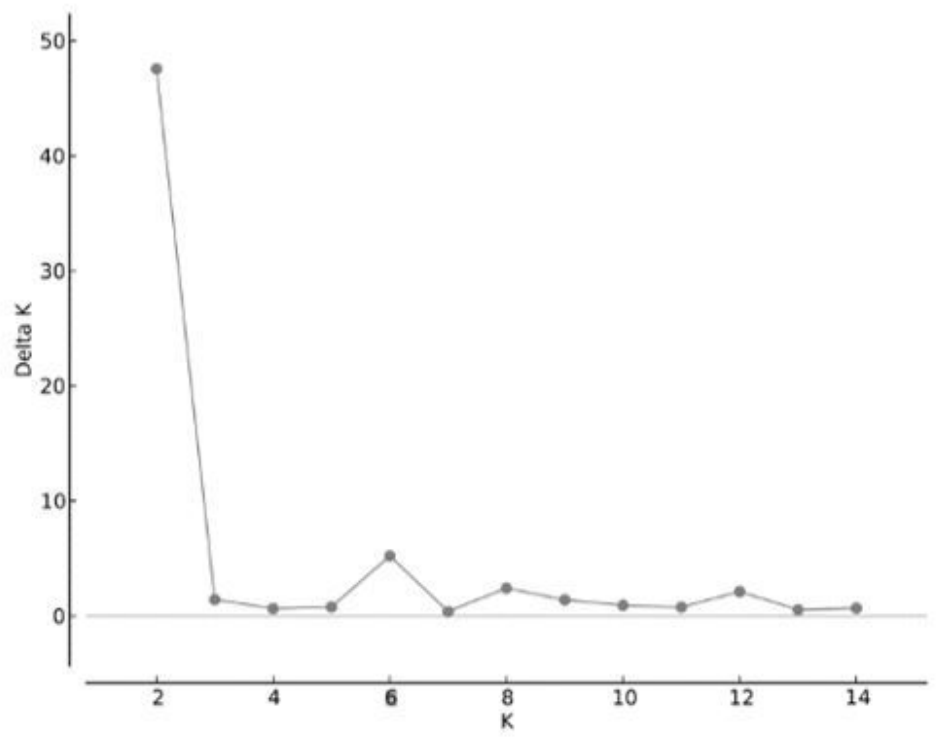

\section{Figure 4}

Squirrel glider Delta K results from the Structure Harvester Evanno method. STRUCTURE tested 15 clusters $(K=1-15)$ with 8 replicates each. DeltaK $=$ mean $\left(\left|L^{\prime \prime}(K)\right|\right) / \operatorname{sd}(L(K))$.
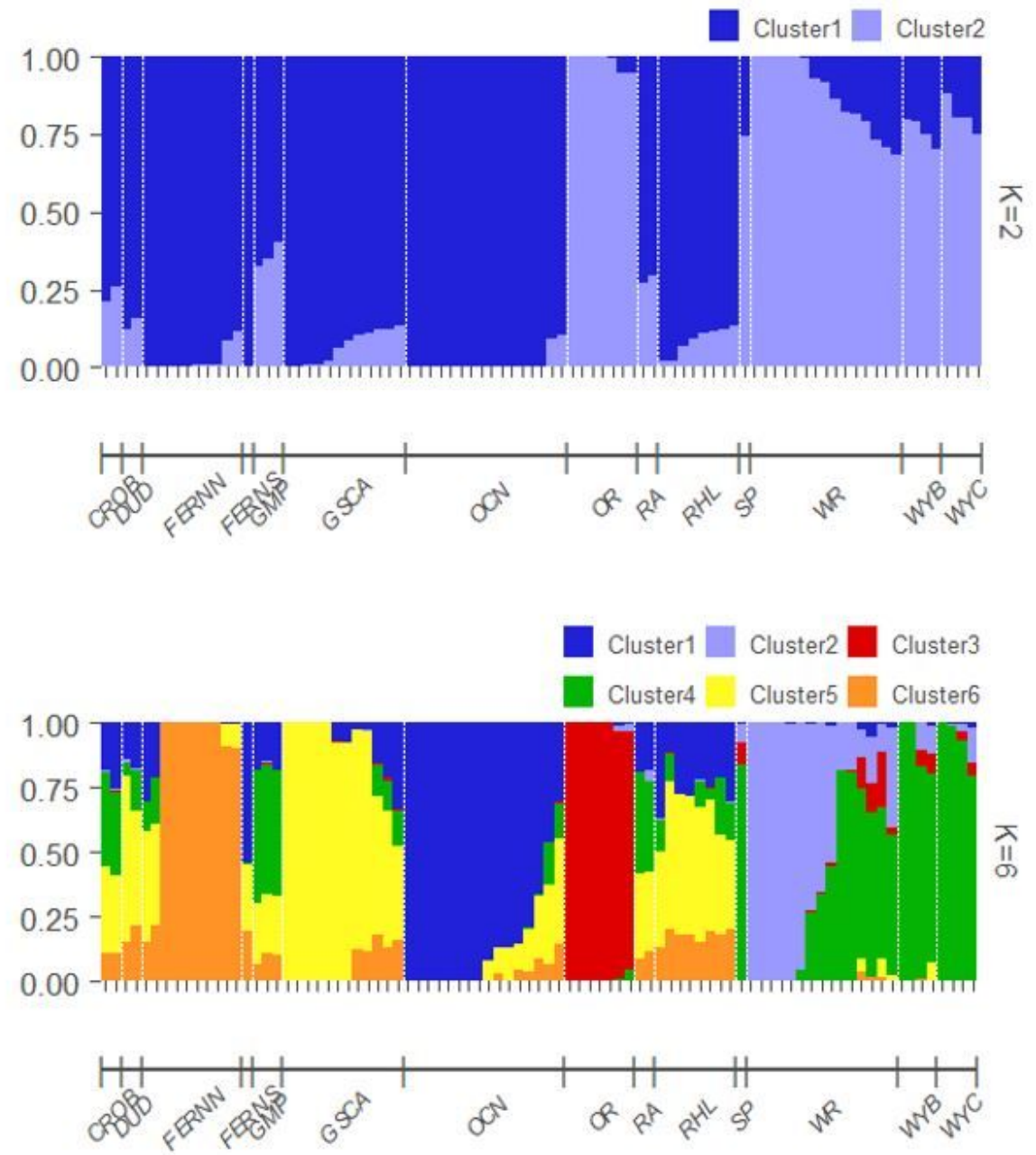

Figure 5 
STRUCTURE admixture results for 87 squirrel glider individuals, 6,812 loci and $\mathrm{K}=2$ (above) and $\mathrm{K}=6$ clusters (below). Each individual is represented by a vertical bar while putative populations are divided by the white dashed lines and labelled below the plot. Each cluster is displayed with a unique colour. Note: The designations employed and the presentation of the material on this map do not imply the expression of any opinion whatsoever on the part of Research Square concerning the legal status of any country, territory, city or area or of its authorities, or concerning the delimitation of its frontiers or boundaries. This map has been provided by the authors.

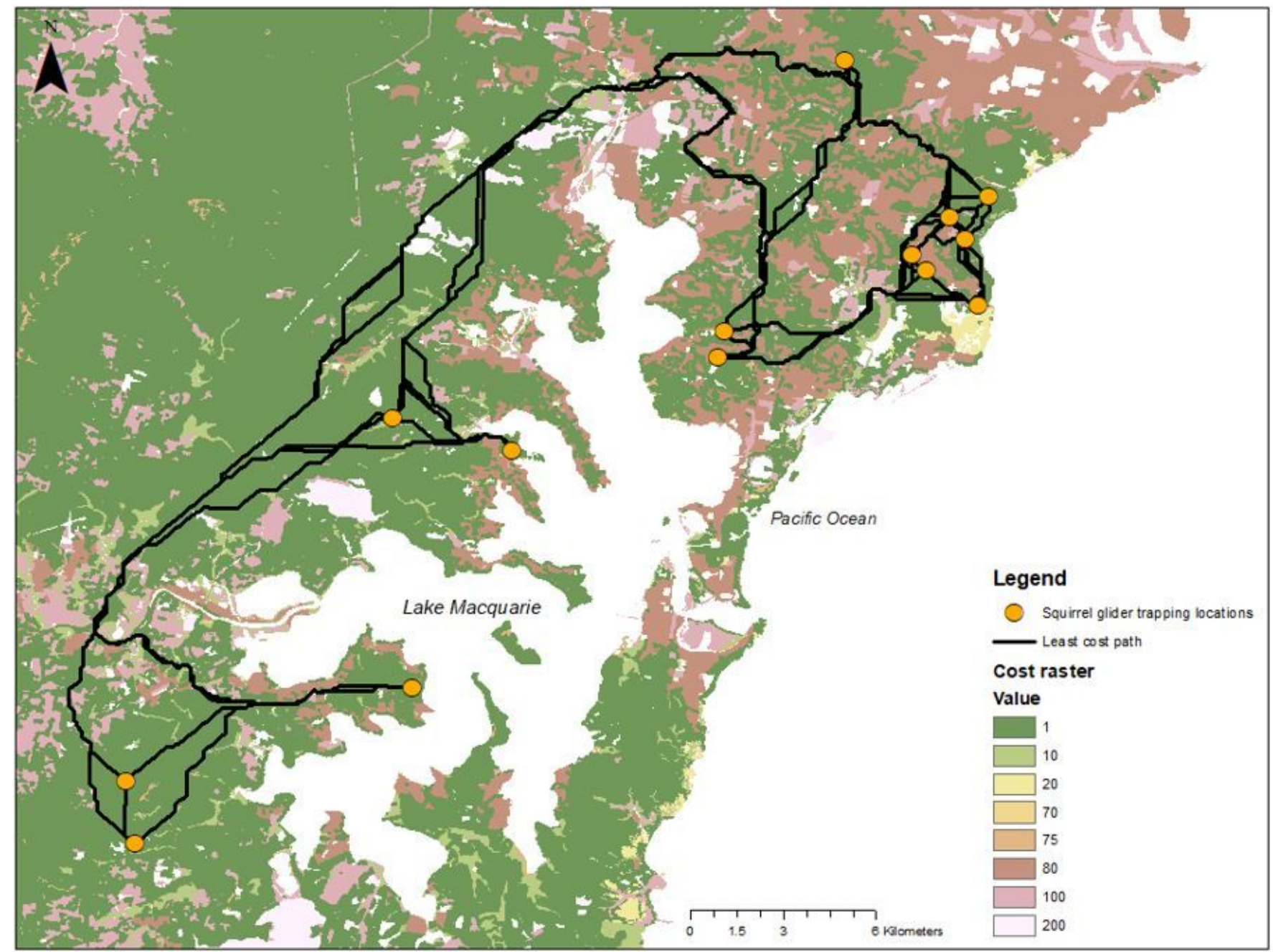

\section{Figure 6}

Friction matrix and least cost paths between 14 squirrel glider populations in Lake Macquarie. Raster was generated in ARCMAP and the least cost paths were created with the package dartR in R. Cost raster cell values ranged from optimal habitat (1) to unsuitable habitat (200) based on vegetation communities and land use type. The lake and ocean were given "NoData" values and assumed a complete barrier to dispersal, except where the vegetation buffer allowed crossing using maximum gliding distance of 70m. Note: The designations employed and the presentation of the material on this map do not imply the expression of any opinion whatsoever on the part of Research Square concerning the legal status of any country, territory, city or area or of its authorities, or concerning the delimitation of its frontiers or boundaries. This map has been provided by the authors. 

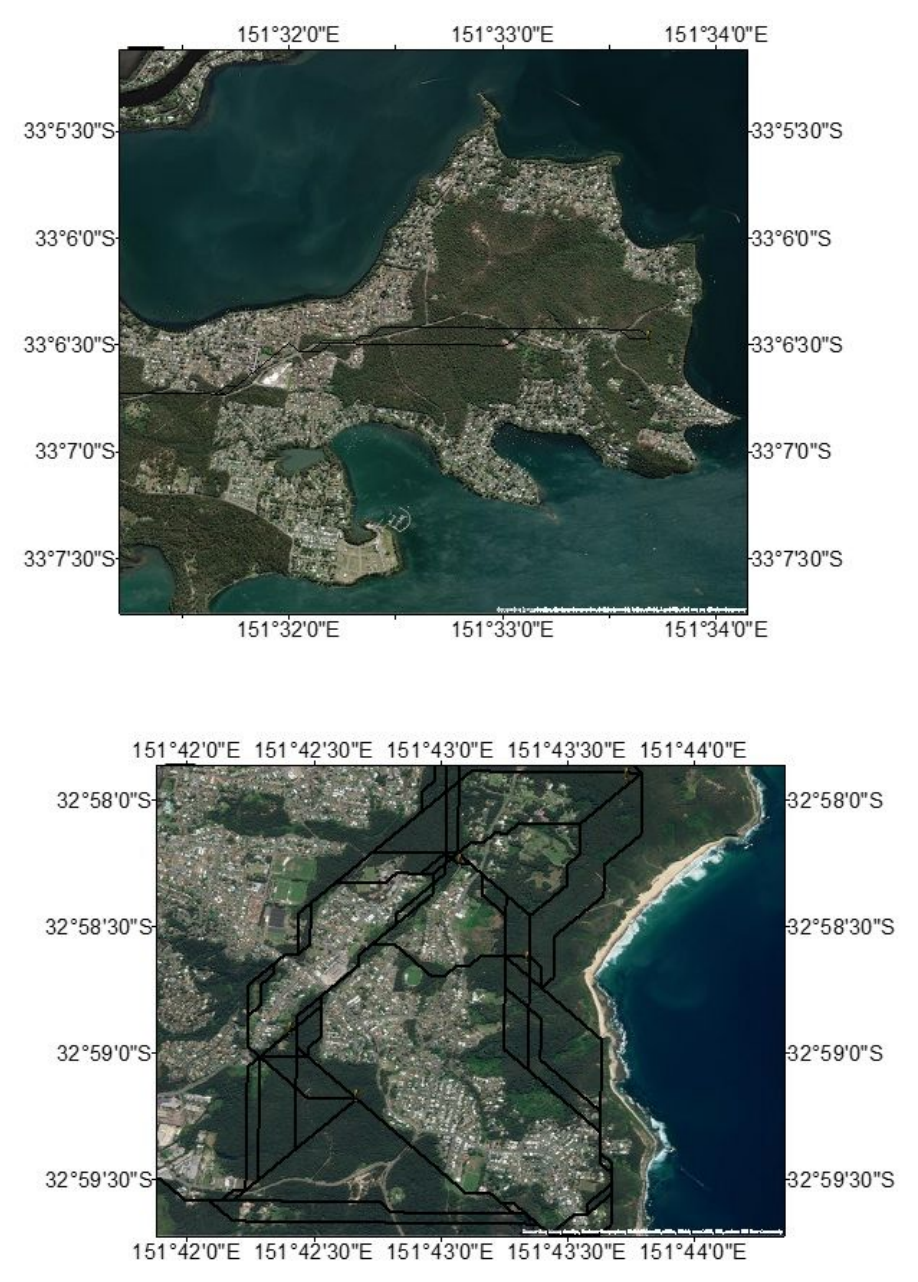

\section{Figure 7}

Examples of thin corridors that need conservation for the continued gene flow of squirrel gliders. Above: Fishery Point Road (Bonnells Bay) leading to squirrel glider location SP. Below: Fernleigh Track (Whitebridge) and vegetation west of Fernleigh Track (Charlestown) connecting squirrel glider locations FERNS and OCN (south) with FERNN, DUD and GSCA (north). Yellow dots indicate trapping locations where squirrel glider samples were collected. Black lines are least cost paths between these locations. Note: The designations employed and the presentation of the material on this map do not imply the expression of any opinion whatsoever on the part of Research Square concerning the legal status of any country, territory, city or area or of its authorities, or concerning the delimitation of its frontiers or boundaries. This map has been provided by the authors.

\section{Supplementary Files}

This is a list of supplementary files associated with this preprint. Click to download.

- Knipleretal2021P.norfolcensisAPPENDIX.docx 